\title{
CESPUC
}

\section{MARCAS DE PESSOALIDADE EM DOCUMENTOS OFICIAIS DOS MUNICÍPIOS MINEIROS DIRIGIDOS AO TCEMG: POSSIVELL ATUAÇÃO-ORIENTAÇÃO DO PROFISSIONAL REVISOR}

\author{
Romero de Assis Caixeta*
}

\section{Resumo}

O presente artigo trata das ocorrências de marcas de pessoalidade presentes nos documentos dos gêneros oficiais encaminhados ao Tribunal de Contas do Estado de Minas pelos responsáveis dos órgãos da Administração Pública Direta ou Indireta dos municípios mineiros. Após proceder ao exame das múltiplas ocorrências, apontamos como se materializam nos textos pesquisados e quais se apresentam com mais frequência. $\mathrm{O}$ artigo funcionará, ainda, como espaço de reflexão acerca da possível atuação do profissional revisor de texto no âmbito do órgão público remetente, com vistas ao aprimoramento da redação final desses documentos.

Palavras-chave: Marcas de Pessoalidade. Documentos Oficiais. Municípios Mineiros. TCEMG.

\section{MARQUES PERSONNELLES DANS LES DOCUMENTS OFFICIELS DES MUNICIPALITÉS DE L'ÉTAT DE MINAS GERAIS ENVOYÉS À LA COUR DE COMPTES DE L'ETAT: POSSIBLE RÔLE ET ORIENTATION DU RÉVISEUR DE TEXTES PROFESSIONEL}

Resumé

Cet article traite des occurrences des marques personnelles trouvées dans les documents dont les textes sont classés parmi les genres officiels qui ont été envoyés à la Cour des Comptes de État de Minas Gerais par les dirigeants des organismes de l'Administration Publique Directe ou Indirecte des municipalités de l'État. Après l'examen de multiples occurrences, nous montrons comment elles se matérialisent dans les textes et quelles sont les plus courantes. L'article fonctionnera également comme un espace de réflexion sur le rôle possible du professionel réviseur de textes dans l'organisme publique de l'expéditeur, visant à améliorer la version finale de ces documents.

Mots-clés: Marques personnelles. Documents officiels. Municipalités de Minas Gerais. Cour de Comptes de Minas Gerais.

Recebido em 05/04/2017

Aceito em 01/09/2017

* Especialista em Revisão de Textos pelo IEC PUC Minas. Este artigo constitui o Trabalho de conclusão de curso apresentado ao Curso de Pós-Graduação em Letras da PUC Minas Virtual, como requisito parcial para obtenção do título de Especialista em Revisão de Textos. Orientador: Prof. Dr. Cristiano Florentino 


\section{Introdução}

O presente artigo trata das ocorrências de marcas de pessoalidade em documentos cujos textos podem ser classificados dentre os gêneros oficiais, especificamente aqueles encaminhados pelos chefes dos poderes da Administração Pública dos municípios mineiros ou por dirigentes das entidades da administração indireta municipal ao Tribunal de Contas do Estado de Minas Gerais - TCEMG -, e busca apontar como tais marcas se materializam no texto e quais se revelam mais comuns.

O autor, servidor público estadual, trabalha, no TCEMG, nas áreas de redação e de revisão dos atos oficiais (expedientes, despachos e decisões) que respondem a documentos remetidos, em sua maioria, por prefeituras e por câmaras legislativas de municípios do Estado de Minas Gerais. Além dessas entidades, órgãos da administração indireta, estes em menor quantidade, também enviam documentos com as mesmas finalidades daqueles encaminhados pelos chefes dos Poderes Executivo e Legislativo.

Não obstante tratar-se, em regra, de comunicação entre órgãos públicos, notamos que, em muitos desses documentos, há escolhas lexicais que denotam uma forte marca de pessoalidade, comumente por meio de expressões que chamam a atenção para a pessoa do emitente e/ou do destinatário em situações que, entretanto, são claramente regidas por atos normativos. Por exemplo: constata-se o uso, nos parágrafos finais de ofícios, de expressões como "certo de poder contar com sua compreensão" após requerer prorrogação de prazo fixado para cumprir alguma determinação ou obrigação, cujo deferimento ou indeferimento não depende da compreensão e da sensibilidade da autoridade destinatária, mas sim, do que o ato normativo estipula.

O artigo trata, ao final, de uma possível causa para a ocorrência desta característica dos textos oficiais examinados, devendo ser considerados os seguintes fatores:

a) os documentos oficiais são subscritos por agentes políticos eleitos pelo voto popular (prefeitos municipais e presidentes das câmaras legislativas ou seus procuradores regularmente constituídos) ou por administradores nomeados por aqueles chefes dos Poderes (dirigentes das entidades da administração indireta municipal ou seus procuradores regularmente constituídos);

b) a maior parte dos membros do TCEMG são originários de carreira política, de expressão regional ou estadual, alguns tendo sido já deputados, atuando na Assembleia Legislativa do Estado de Minas Gerais;

c) o TCEMG tem competências formalmente descritas pela Constituição Estadual, pela Lei Orgânica e pelo Regimento Interno.

Neste cenário, este artigo constitui-se como um espaço de reflexão acerca da possível atuação do profissional revisor de texto no âmbito do órgão público remetente, com vistas ao aprimoramento da redação final desses documentos. 


\section{CESPUC \\ 20 SEMESTRE DE $2017-$ N. 31}

\section{Revisão de literatura}

O artigo 37 da Constituição federal dispõe que a Administração Pública direta e indireta de qualquer dos Poderes da União, dos Estados, do Distrito Federal e dos Municípios obedecerá aos princípios de legalidade, impessoalidade, moralidade, publicidade e eficiência. Esses princípios devem não somente nortear a conduta, sob o ponto de vista da ética, dos agentes políticos e dos ocupantes dos vários cargos da Administração Pública, mas também se materializar por meio dos textos oficiais.

Textos oficiais, escritos segundo as diretrizes da redação oficial (maneira pela qual o Poder Público redige atos normativos e comunicações, conforme Manual da Presidência da República), são aqueles que tratam de assuntos que correspondem à atuação da Administração Pública (BRASIL, 2002, p. 4). Devido aos seus fatores intrínsecos - quem comunica é sempre o Serviço Público, o que se comunica é assunto relativo às atribuições do órgão emissor ou a questões de caráter público, e o destinatário dessa comunicação é um cidadão, sempre concebido como público, como conjunto dos cidadãos, ou é um órgão público (BRASIL, 2002, p. 9) -, os textos oficiais devem obedecer a normas de padronização e a regras de forma.

É indispensável que nos documentos oficiais se utilize o padrão culto da língua, ou seja, aquele em que são respeitadas as regras da gramática formal e em que a seleção do vocabulário se dá considerando o conjunto dos usuários do idioma. Os manuais de redação oficial, a exemplo do Manual de Redação da Presidência da República (2002) e do Manual de Redação Oficial do Governo do Estado de Minas Gerais (2012), ensinam que

(...) a obrigatoriedade do uso do padrão culto na redação oficial decorre do fato de que ele está acima das diferenças lexicais, morfológicas ou sintáticas regionais, dos modismos vocabulares, das idiossincrasias linguísticas, permitindo, por essa razão, que se atinja a pretendida compreensão por todos os cidadãos. (BRASIL, 2002, p. 13).

\section{O Manual de Redação Parlamentar da Assembleia Legislativa do Estado de Minas}

Gerais ressalta que "a formalidade, no grau em que ocorre na esfera pública, não pode ser confundida com eruditismo", da mesma forma que a esperada simplicidade, que propicia a citada compreensão pelos cidadãos em geral, "deve ser distinguida da vulgaridade" (MINAS GERAIS, 2013, p. 23).

Considerando que o processo envolvido na comunicação oficial (quem comunica, o que e a quem se comunica) é uma manifestação da Administração Pública dirigida à coletividade, torna-se essencial a ausência de impressões individuais do emissor da informação. Dessa forma, não há espaço nos documentos oficiais para uma dicção pessoal, idiossincrásica, evitando-se a manifestação de opiniões sobre o assunto tratado. 


\section{CESPUC}

No caso da redação do ofício, ainda que haja, de um lado, uma autoridade ou um servidor de órgão público que o assine e, de outro, um destinatário, o princípio da impessoalidade, "basilar na informação dos atos da administração pública das três esferas de Poder", deverá ser observado, uma vez que, como qualquer outra correspondência oficial, colocam-se em relação dois órgãos, não dois indivíduos (MINAS GERAIS, 2013, p. 291; 249). Assim é que, no lugar de marcas de pessoalidade e de estilo autoral, no lugar de traços de espontaneidade e de intimidade, no ofício encontram-se - ou, idealmente, deveriam encontrar-se - fórmulas impessoais, que guardam relação com a padronização.

Cite-se, por exemplo, o fecho dos ofícios, parágrafo final que arremata o texto e saúda o destinatário: as recomendações dos manuais de redação oficial, em suas últimas edições, trazem apenas dois modelos - "atenciosamente" e "respeitosamente" ${ }^{1}$-, utilizados segundo a combinação entre o nível de hierarquia do remetente e o do destinatário. Significa dizer que não há qualquer outro fator, como o grau de proximidade entre emissor e receptor ou o conteúdo do texto, que oriente a escolha do fecho. Conclui-se que, a rigor, não há escolha.

Assim, neste trabalho, analisaremos a ocorrência de marcas de pessoalidade em textos de âmbito oficial, que se colocam em conflito com os direcionamentos legais e didáticos a esse respeito.

\section{Metodologia}

Para a realização da presente pesquisa, procedemos ao exame, à luz dos manuais que tratam dos fundamentos do texto oficial, particularmente quanto à redação e à revisão, de alguns documentos originários de órgãos públicos municipais dirigidos ao TCEMG, nos quais verificamos, após leitura inicial, a existência, em seu corpo, de marcas de pessoalidade.

Para a análise dos textos, ativemo-nos aos itens por meio dos quais o remetente pode, voluntária ou involuntariamente, transformar uma correspondência impessoal em uma carta equivocadamente com número de ofício ou um requerimento administrativo em um pedido pessoal: adequação do texto ao gênero, escolha do vocativo, uso dos pronomes de tratamento (aspecto da formalidade), uso de expressões subjetivas e fecho.

Para a discussão acerca dos resultados, foram consideradas, também, as competências constitucionais e os documentos legais que tratam do funcionamento do TCEMG: Constituição do Estado de Minas Gerais, Lei Complementar n. ${ }^{\circ}$ 102/2008 (Lei Orgânica do TCEMG) e Resolução TCEMG n. ${ }^{\circ}$ 12/2008 (Regimento Interno), entre outros atos normativos quando necessários à contextualização.

Vale ressaltar que os demais aspectos pertinentes à redação oficial (clareza, objetividade, concisão, uniformidade, etc.) e às práticas de construção textual (uso estético da página,

1 Importa ressaltar que esta prescrição é bastante anterior aos modernos manuais de redação oficial, vigorando desde a publicação da Instrução Normativa n. ${ }^{\circ} 4$, de 6 de março de 1992, da já extinta Secretaria da Administração Federal (cf. LIMA, 2005, p. 8). 


\section{CESPUC \\ 20 SEMESTRE DE $2017-$ N. 31}

seleção vocabular, dicção própria do redator e/ou do subscritor, construção frasal, coesão e coerência, adequação às normas sintáticas, etc.) não são objeto desta pesquisa. Entretanto, na medida em que se pode afirmar que uma propriedade não se sustenta sem a outra, poderão ser mencionados quando verificarmos inter-relação entre a violação de qualquer destes aspectos e a presença dos traços de pessoalidade investigados.

\section{O Tribunal de Contas do Estado de Minas Gerais}

\subsection{Descrição}

O Tribunal de Contas, órgão de controle externo da gestão dos recursos públicos e municipais, foi criado no Estado de Minas Gerais pela edição da Constituição mineira de 1935 e presta auxílio ao Poder Legislativo. Tem sede na Capital e jurisdição própria e privativa sobre as matérias e pessoas sujeitas a sua competência. $\mathrm{O}$ controle por ele exercido compreende a fiscalização contábil, financeira, orçamentária, operacional e patrimonial, e abrange os aspectos de legalidade, legitimidade, economicidade e razoabilidade de atos que gerem receita ou despesa pública.

A Constituição estadual de 1989 (MINAS GERAIS, 2015), em seu art. 76, estabeleceu as diretrizes das ações do controle externo, consolidadas e detalhadas pela Lei Complementar n. ${ }^{\circ}$ 102, de 17 de janeiro de 2008 (Lei Orgânica do Tribunal de Contas). Esse é o diploma legal que define a jurisdição e competências do TCEMG.

\subsection{Os membros do TCEMG}

A instância coletiva de decisão do TCEMG é composta pelos Conselheiros. Segundo a Lei Orgânica do Tribunal de Contas (Lei Complementar n. ${ }^{\circ}$ 102, de 2008), em seu Título I (Do Tribunal de Contas), Capítulo II (Da Composição e Organização), Seção I (Disposições Gerais):

Art. $8^{\circ}$ Os Conselheiros serão escolhidos:

I - três pelo Governador do Estado, com a aprovação da Assembléia Legislativa, sendo:

a) um, dentre Auditores indicados em lista tríplice, segundo os critérios de antiguidade e merecimento, alternadamente;

b) um, dentre Procuradores do Ministério Público junto ao Tribunal indicados em lista tríplice, segundo os critérios estabelecidos na alínea "b" deste inciso; [sic]

c) um de sua livre nomeação;

II - quatro pela Assembleia Legislativa. 


\section{CESPUC}

$\mathrm{O}$ art. $7^{\circ}$ da Lei Orgânica dispõe que os requisitos para ser nomeado Conselheiro do Tribunal são: ser brasileiro com idade entre 35 e 60 anos, devendo ter idoneidade moral e reputação ilibada, bem como possuir notórios conhecimentos jurídicos, contábeis, econômicos e financeiros ou de administração pública, além de contar com mais de 10 anos de exercício de função ou de efetiva atividade profissional que exija os conhecimentos mencionados.

Como se vê, qualquer cidadão brasileiro que preencha estes requisitos pode, em tese, ser nomeado Conselheiro do Tribunal de Contas. No entanto, o órgão vem seguindo a tradição de ter na composição de seu Colegiado, dentre as quatro nomeações a cargo da Assembleia, apenas deputados que compunham o Legislativo estadual após sucessivas vitórias em disputas eleitorais. De forma semelhante, os últimos governadores do Estado que, em caso de vacância do cargo de Conselheiro, procederam às nomeações de sua livre escolha selecionaram personalidades do mundo da política de expressão regional ou estadual. ${ }^{2}$

Quanto aos Auditores, os artigos 24 e 25 da Lei Orgânica do TCEMG dispõem que são servidores públicos estaduais nomeados pelo governador do Estado após aprovação em concurso público de provas e títulos, detentores de diploma de curso superior, e que devem satisfazer os mesmos requisitos exigidos para o cargo de Conselheiro. Com efeito, o Auditor do TCEMG faz parte da única classe de servidores que pode substituir o Conselheiro, conforme incisos I e II do artigo 27, nas suas faltas e impedimentos e no caso de vacância do cargo deste até novo provimento, com as mesmas garantias e impedimentos.

Os Procuradores do Ministério Público junto ao Tribunal de Contas são também nomeados pelo Governador do Estado mediante aprovação em concurso público de provas e títulos, em cuja realização é assegurada a participação da Seção Minas Gerais da Ordem dos Advogados do Brasil. São exigidos do candidato o grau de bacharel em Direito e o mínimo de três anos de atividade jurídica (artigos 28 e 29 da Lei Orgânica do TCEMG).

\subsection{Documentos oficiais encaminhados ao TCEMG}

A maior parte dos documentos recebidos pelo TCEMG é originária dos poderes da administração dos municípios do estado, sendo os respectivos textos subscritos por agentes políticos eleitos pelo voto popular ou por administradores das entidades municipais nomeados por aqueles agentes políticos. Quando se referem a processos que tramitam na Corte de Contas, os documentos são necessariamente protocolizados na Coordenadoria de Protocolo e Triagem, onde recebem número, e posteriormente juntados aos respectivos processos ou submetidos à consideração da autoridade que tenha competência regimental para determinar o destino dos

2 Registre-se que, nas últimas cinco ocasiões em que a escolha era de responsabilidade da Assembleia Legislativa, o Sr. Alexandre Bossi, doutor em Contabilidade e Finanças, especialista em Gestão Pública, professor universitário e consultor concursado da Assembleia Legislativa de Minas Gerais, candidatou-se ao cargo de Conselheiro, "acreditando que a capacidade técnica deve se sobrepor aos interesses políticos", tendo sido preterido em favor de ex-deputados (cf. alexandrebossi.com.br). 


\section{CESPUC \\ 2O SEMESTRE DE $2017-$ N. 31}

documentos. Aqueles que não são relativos a processos em tramitação, mas que se referem a matéria cuja análise seja atribuição do Tribunal, também são protocolizados e devem receber um parecer técnico acerca de seu teor, podendo vir a ser transformados em processo ou não.

Para efeitos deste artigo, os documentos oficiais que se identifiquem com as situações mencionadas no parágrafo anterior serão denominados "correspondência técnica".

Documentos dirigidos ao TCEMG que não tratem de matéria técnica ficam automaticamente excluídos do conjunto de possibilidades de exame pertinente a esta pesquisa, uma vez que, a depender do teor do texto, naturalmente devem conter as marcas de pessoalidade por motivo de deferência, civilidade, relacionamento entre remetente e destinatário, etc. Assim são os convites para festividades, cartas de agradecimento ou de congratulações, comunicações de posse, declarações, telegramas, etc.

No campo reservado ao destinatário, as correspondências técnicas indicam, mais frequentemente, o órgão TCEMG ou algum dos membros que compõem a instância coletiva de decisão, os Conselheiros. Em raras vezes, o destinatário pode ser um setor ou um servidor do Tribunal que tenha, por exemplo, assinado uma comunicação que deveria ser respondida.

Acrescentamos, para melhor compreensão da natureza das correspondências técnicas que devem ser dirigidas à análise do Tribunal de Contas, que este, entre outras atribuições constitucionais, é órgão auxiliar do Poder Legislativo estadual e dos Legislativos municipais no que diz respeito ao controle externo sobre as contas do estado de Minas Gerais e dos municípios, respectivamente, mas que apresenta, ao mesmo tempo, interface com a Justiça, uma vez que profere despachos e emite votos sobre as condutas de gestão dos responsáveis pela administração, bem como que suas decisões têm eficácia de título executivo, quando acarretam imputação de débito ou multa.

\section{0 revisor de textos}

\subsection{Aspectos gerais}

A atividade do revisor guarda relação com a verificação das bases gerais da boa escrita da língua portuguesa. O profissional, diante do seu material de trabalho, busca a supressão dos erros, pretendendo um texto sem lapsos de nenhum tipo. Em outras palavras, há que se pensar na natureza da escrita sob o ponto de vista da morfossintaxe culta e avaliar o grau de sua aplicabilidade, de modo a evitar no trabalho final, no dizer de Yamazaki (2007), a ocorrência tanto de "fraturas gramaticais" quanto de "fissuras da linguagem". 3

3 Apresentamos a ressalva de que, a depender do gênero e do conteúdo do texto trabalhado pelo profissional revisor, como um conto literário, talvez sejam as fraturas/ fissuras características esperadas. 


\section{CESPUC \\ 2O SEMESTRE DE $2017-$ N. 31}

No entanto, os estudiosos, cada um em sua área de investigação, são categóricos ao afirmar que a prática do revisor não se restringe a esse caráter verificador de inadequações, eliminador de ocorrências não previstas pelas gramáticas normativas e pelos dicionários. De fato, não basta ao material estar correto do ponto de vista das regras gramaticais e/ou ortográficas, uma vez que pode haver muitas outras inconsistências passíveis de se valer do trabalho de revisão. Assim é que Yamazaki (2007) e D’Andrea \& Ribeiro (2010), ao pesquisarem sobre o tratamento do texto nos ambientes editoriais, apontam que, para a reprodução de um texto refinado, o foco, para além da observação do erro, deve passar ao exame da legibilidade. Esses autores definem legibilidade "como uma característica da construção linguística do texto", obtida a partir da reflexão por revisores profissionais sobre estruturas e modos de escrever, o que conduzirá à reescrita, a fim de ser apresentado ao público, com qualidade, "o livro que um dia esse texto será" (D'ANDREA; RIBEIRO, 2010, p. 72). ${ }^{4}$

Em linha semelhante são as conclusões de Rodrigues, discorrendo sobre a necessidade de se considerar o aspecto interacional nos textos institucionais:

(...) a eficácia da escrita institucional relaciona-se não só ao domínio da variedade culta da língua, mas, também, ao domínio das regras interacionais para que a interação se efetive adequada e satisfatoriamente. (...) Assim, a atividade do revisor de textos institucionais deve se pautar, sobretudo, nos aspectos do jogo interacional que se estabelece entre os interlocutores (diretores, funcionários, clientes etc.). (RODRIGUES, 2010, p. 154).

\subsection{O revisor de textos dos gêneros oficiais}

O profissional da redação e da revisão é, dentro de todo o processo que comporta a elaboração textual em órgãos públicos, quem vai adequar a correspondência, o ofício, às características da redação oficial, considerando o conhecimento - que deve ter - acerca do assunto tratado e a situação específica da elaboração do documento. A esse profissional cabe verificar - e reparar, se for o caso - a coerência de ideias e o encadeamento de argumentos, com vistas à construção de um texto da maior qualidade possível, ou seja, o revisor lida com seu material de trabalho do ponto de vista da forma e do conteúdo.

Com efeito, mais do que conhecimentos linguísticos, que necessariamente deve dominar, Ribeiro afirma que "o revisor precisa ler, entender, compreender o conteúdo e, assim, corrigir problemas" (SAATKAMP apud RIBEIRO, 2007, p. 8). É adequada também à revisão de textos dos gêneros oficiais a conclusão da autora quanto às atividades do editor de textos e do revisor na produção de livros:

4 As autoras Coelho e Antunes esclarecem que talvez a ideia "do revisor como mero corretor (...) esteja mais difundida quando se trata da revisão textual como uma prática de auxílio no ensino da escrita (...) do que quando se aborda a revisão profissional" (COELHO; ANTUNES, 2010, p. 206). 
A importância do revisor e do copidesque se aloja na necessidade de conferir legibilidade (ou inteligibilidade) aos textos, uma leitura perspicaz e especializada em obra que não deveria circular sem certos ajustamentos. (...) é plenamente reconhecível [sic] um produto bemtratado e um outro que tenha negligenciado as fases de produção de obras (...). (RIBEIRO, 2007, p. 13).

A depender de quem redige e/ou subscreve, podem ser desconsideradas as características intrínsecas aos atos oficiais escritos, tanto intencionalmente, ao procurar se relacionar com o interlocutor de forma submissa e pessoal, quanto involuntariamente, por desconhecer que se trata de um produto que tem guias de feitura específicas ou, até mesmo, pela diversidade de perfis de instrução que a população exibe, isto é, o subscritor e/ou o redator talvez simplesmente não saibam das muitas especificidades da correspondência oficial, cujo conhecimento pressupõe acesso ao saber institucionalizado. Num ou noutro caso, o revisor terá em mãos um material em estado quase bruto, que precisará passar por melhoramentos que o tornem adequado à leitura.

Assim, podemos afirmar que é indispensável ao profissional de revisão de textos de um órgão público deter conhecimentos a respeito das normas sintáticas e da ortografia vigente, das técnicas de construção de textos, bem como das diretrizes específicas da redação dos documentos dos gêneros oficiais, de acordo com os vários manuais existentes (se o órgão em que trabalha ainda não o tiver), e, por último - e isso também se aplica a todo profissional revisor de qualquer área de desempenho -, deve ter conhecimento acerca do assunto tratado no documento a ser revisado. Eis um dos motivos por que o ofício do revisor ${ }^{5}$ exige uma formação constante, não apenas no sentido da atualização da bagagem intelectual, mas também do aprimoramento dos domínios do saber e do fazer (PERPÉTUA; GUIMARÃES, 2010); assim, o profissional terá condições de adentrar com propriedade o assunto relativo às prescrições da redação oficial e ao conteúdo a ser tratado, o que lhe dará uma faixa mais ampla de possibilidades de operações às quais deverá submeter o texto.

\section{Resultados e discussão}

Cumpre-nos informar que as correspondências técnicas enviadas ao TCEMG pelas entidades da administração direta e indireta de alguns municípios mineiros, subscritas por seus responsáveis, que foram tomadas para análise, por razões éticas, não se encontram relacionadas na íntegra, porém tiveram transcritos os trechos pertinentes a nosso estudo. O corpus constituiu-se de 11 (onze) textos, sendo 1 carta, 6 ofícios e 4 requerimentos.

Passamos agora à análise das correspondências e à discussão acerca dos resultados observados nesta pesquisa. Para o exame, foram considerados os seguintes parâmetros: gênero,

5 Propositadamente, procedemos a essa escolha lexical para a composição da expressão "ofício do revisor" com o objetivo de apontar tanto para uma característica da ocupação do revisor quanto para uma exigência de um dos produtos do profissional do âmbito dos órgãos públicos. 


\section{alemes

endereçamento, vocativo, pronome de tratamento referente ao destinatário, fecho-chavão e fecho.

\subsection{Gênero}

Sendo os remetentes chefes dos poderes da administração direta ou dirigentes de entidades da administração indireta municipal, o gênero apropriado para se dirigir ao TCEMG, quando comunicarem/ solicitarem em nome dos seus respectivos órgãos, é o ofício.

Os textos 10 e 11 veiculam uma característica própria. O remetente do requerimento 10 se reportou à autoridade que preside a tramitação do processo em que é responsável tendo em vista que recebeu intimação para se defender diante das irregularidades verificadas em seus atos de gestão. Assim, encaminha, na qualidade de chefe de Poder Público, mas em seu próprio nome, requerimento por meio do qual solicita prazo para se manifestar no processo:

Figura 1 - Texto 10

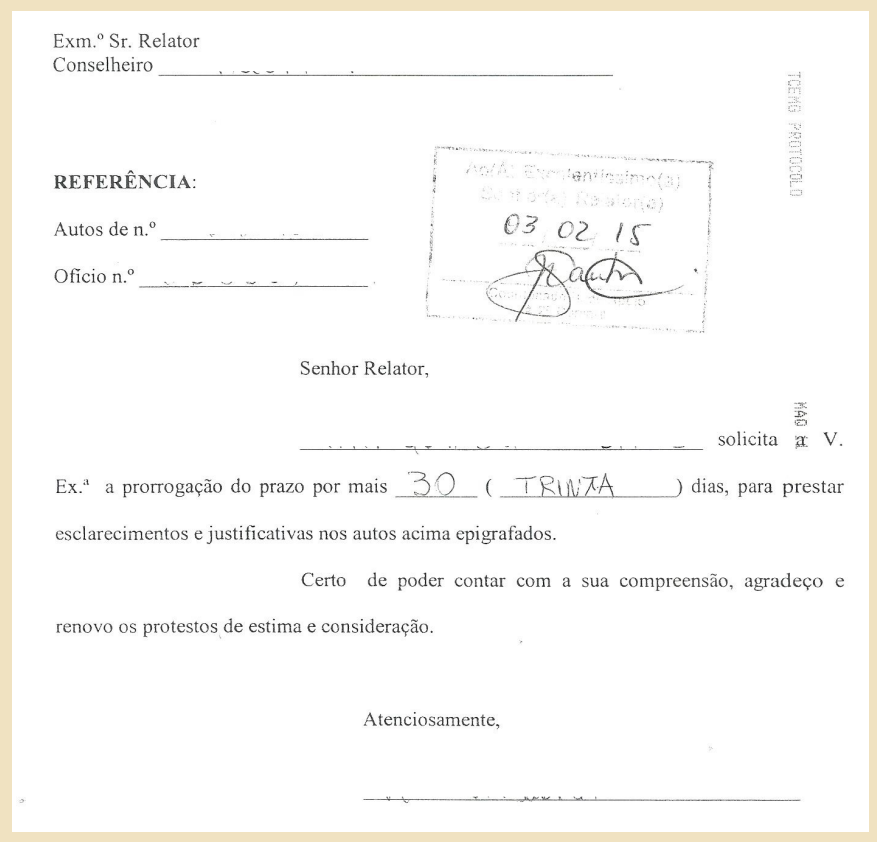

Fonte: dados da pesquisa

O subscritor do requerimento 11 , chefe de Poder Público no município em que reside, foi apenado pelo TCEMG com a aplicação de multa pessoal em decorrência de conduta incompatível com o governo responsável, ou seja, a sanção não recaiu sobre a entidade, mas sobre a pessoa do gestor. Assim, em vez de redigir ofício, é apresentado ao membro do TCEMG incumbido de presidir a tramitação do respectivo processo o requerimento no qual se identifica adequadamente como agente político e faz sua solicitação relativa à punição pessoal. 
DD. Relator Autos

brasileiro, portador do CPF

, na qualidade de Presidente da Câmara Municipal de

presença de V. Exa. para dizer que não pretende recorrer da decisão do processo supra, requerendo o parcelamento da multa em 04 parcelas.

Termos em que pede deferimento

\section{Fonte: dados da pesquisa}

Curiosamente, entre as correspondências técnicas que compõem o corpus desta pesquisa, o texto 11 é a único exemplar no que diz respeito à observância das prescrições da redação oficial (ainda que não se possa também dizer que esteja perfeita do ponto de vista linguístico).

Quadro 1 - síntese do exame dos textos quanto ao parâmetro "gênero"

\begin{tabular}{|c|c|c|}
\hline Texto & Gênero apresentado & Análise \\
\hline 1 & Requerimento & Inapropriado \\
\hline 2 & Carta & Inapropriado \\
\hline 3 & Ofício & Apropriado \\
\hline 4 & Ofício & Apropriado \\
\hline 5 & Ofício & Apropriado \\
\hline 6 & Requerimento & Inapropriado \\
\hline 7 & Ofício & Apropriado \\
\hline 8 & Ofício & Apropriado \\
\hline 9 & Ofício & Apropriado \\
\hline 10 & Requerimento & Apropriado \\
\hline 11 & Requerimento & Apropriado \\
\hline
\end{tabular}

Fonte: dados da pesquisa.

Portanto, os documentos redigidos no formato de requerimento (textos 1 e 6) e de carta (2) foram considerados inapropriados.

A exceção quanto à exigência do gênero ofício, conforme já mencionado, são as correspondências constantes nos textos 10 e 11 (são requerimentos); além disso, a título de 
observação, verifiquem-se as correspondências técnicas de $n^{\circ} 4$ (nomeada "ofício", porém o que se tem é um equerimento.

\section{Figura 3 - Texto 4}

Prezados (as) Senhor (es) (as),

A CAIXA DE APOSENTADORIA E PENSÃO DOS SERVIDORES PÚBLICOS DO MUNICÍPIO DE

da sua Representante legal,

vem através deste, requerer o seguinte:

Reabertura de prazo no FISCAP para resposta das intimações nos processos de concessão de benefícios $n^{\circ}$

Informamos que as retificações solicitadas por este Egrégio Tribunal já foram efetuadas, porém o prazo para envio via FISCAP das informações e documentos comprobatórios estão expirados.

Assim sendo, solicito a liberação no sistema para que possamos regularizar a situação no FISCAP, bem como obter o registro dos referidos atos.

Nestes termos, peço deferimento.

Fonte: dados da pesquisa

\subsection{Endereçamento}

Consoante os manuais de redação consultados, o endereçamento dos ofícios, ao final da primeira página, deve trazer a forma de tratamento aplicável ao destinatário, o nome da autoridade, o cargo e a localidade de destino.

Segundo as normas do Regimento Interno do TCEMG (especialmente os artigos 184, 188 e 193), as correspondências técnicas que se refiram a processos devem ser dirigidas ao Conselheiro Presidente ou ao Conselheiro Relator, que é a autoridade responsável pela instrução do processo, conforme o caso. O Tribunal não deixa de receber correspondências que trazem como destinatário o órgão, setores da Casa ou servidores.

No entanto, em obediência às disposições que regem a escritura dos documentos oficiais, consideramos apropriados, para a finalidade desta pesquisa, os documentos que têm, no campo do endereçamento, a forma de tratamento preenchida corretamente.

Quadro 2 -síntese do exame dos textos quanto ao parâmetro "endereçamento"

\begin{tabular}{|c|c|c|}
\hline Texto & Endereçamento apresentado & Análise \\
\hline 1 & Setor do TCEMG & Inapropriado \\
\hline 2 & - & Inapropriado \\
\hline
\end{tabular}




\begin{tabular}{|c|c|c|}
\hline 3 & TCEMG & Inapropriado \\
\hline 4 & TCEMG & Inapropriado \\
\hline 5 & Conselheiro Relator & Apropriado \\
\hline 6 & Conselheiro Relator & Apropriado \\
\hline 7 & Conselheiro Relator & Apropriado \\
\hline 8 & Conselheiro Relator & Apropriado \\
\hline 9 & Conselheiro Relator & Apropriado \\
\hline 10 & Conselheiro Relator & Apropriado \\
\hline 11 & Conselheiro Relator & Apropriado \\
\hline
\end{tabular}

Fonte: dados da pesquisa.

Ressaltamos que demais itens constantes dos endereçamentos das correspondências técnicas considerados equivocados (uso de "DD." - abreviatura abolida pelos manuais de redação -, impropriedades na referência ao cargo, etc.), ainda que detectados, não fazem parte do escopo desta pesquisa.

\subsection{Vocativo}

Os manuais de redação oficial ${ }^{6}$ trazem orientações divergentes quanto ao uso do vocativo de acordo com o destinatário.

Especificamente quanto às remessas de correspondências aos Conselheiros do TCEMG, o Manual de Redação Parlamentar editado pela Assembleia Legislativa do Estado de Minas Gerais (2013) estabelece, à página 336, que o vocativo adequado é "Excelentíssimo Senhor", por extenso. Por sua vez, o Manual de Redação Oficial do Governo do Estado de Minas Gerais (2012) menciona que os presidentes dos tribunais estaduais devem ser interpelados por "Senhor(a) (cargo)" (p. 63), mas é silente quanto ao cargo de Conselheiro. No entanto, tendo em vista que, nos termos do art. 12 da Lei Orgânica do TCEMG, norma repetida no art. $6^{\circ}$ do Regimento Interno, "os Conselheiros terão as mesmas garantias, direitos, prerrogativas, impedimentos, vencimentos e vantagens dos Desembargadores do Tribunal de Justiça do Estado de Minas Gerais", consideramos que o vocativo correspondente a essa autoridade "Senhor(a) (cargo)" (p. 64) - pode ser aplicado.

6 Os manuais de redação oficial são aqui citados a título de consulta, uma vez que cada um tem seu uso destinado a um público delimitado, o que não impede que, mais amplamente, funcionem como fonte de pesquisa e guia de redação. O Manual de Redação Parlamentar da ALMG, por exemplo, traz em seu prefácio que a obra "tem sido um guia seguro para o Parlamento de Minas", ao passo que o Manual de Redação Oficial do Governo de Minas Gerais explica que foi "elaborado para uniformizar a comunicação dos órgãos do Poder Executivo". Não acreditamos que pudesse ser produtivo proceder à presente pesquisa, tendo em vista seu objetivo, buscando saber se cada município mineiro dispõe de manual de redação próprio e, em caso afirmativo, conhecer cada obra. Dessa forma, julgamos válido utilizar os manuais mencionados para o exame do parâmetro "vocativo", considerando, também e principalmente, o estado da federação em que dois deles foram publicados (Manual de Redação Parlamentar da Assembleia Legislativa do Estado de Minas Gerais e Manual de Redação Oficial do Governo do Estado de Minas Gerais) e o público destinatário do terceiro (Manual de Redação Oficial dos Municípios). 
20 SEMESTRE DE $2017-$ N. 31

Da leitura conjunta das prescrições desses dois Manuais, temos que poderá ser aceito também o vocativo abreviado "Exmo. Sr.".

O Manual de Redação Oficial dos Municípios é uma obra de caráter bem geral, e às páginas 17-18, onde o assunto é tratado, não faz referência específica aos tribunais de contas e aos conselheiros. Por exclusão dos demais vocativos discriminados, concluímos que o adequado seria "Senhor (seguido do cargo, função ou condição): para as demais autoridades e cidadãos em geral".

Todos os manuais de redação oficial são taxativos ao asseverar que (trazemos aqui a redação do Manual da Assembleia) “não se usa 'Prezado Senhor' ou 'Prezada Senhora' em ofícios, tratamento informal mais apropriado para a carta, por exemplo" (MINAS GERAIS, 2013, p. 251).

Quanto ao item "vocativo", avaliamos como inapropriadas as correspondências técnicas constantes dos textos 1 e 11 , uma vez que não têm vocativo; do texto 8, por indicar neste campo o órgão ou setor do órgão em vez do pronome relativo ao destinatário; e, principalmente, aqueles dos numerados como 3, 4 e 5, que apresentam a expressão "Prezado Senhor" (e suas flexões encontradas), dado o caráter informal da expressão.

\section{Figura 4 - Texto 08}

Á Presidência do Tribunal de Contas do Estado de Minas Gerais

Utilizamos do presente expediente a fim de informar e requerer a $\mathrm{V}$. Exa., que a coordenadoria da $2^{\text {a }}$ Câmara solicitou diligências referente ao Processo $n^{\circ}$ beneficiário (a)

Fonte: dados da pesquisa 
Figura 5 - Texto 3

Prezados Senhores:

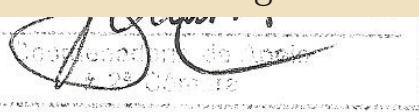

Ref.: Processo Administrativo n. ${ }^{\circ}$ $-2^{\mathrm{a}}$ Câmara - Tribunal de

Contas do Estado de Minas Gerais.

Comunicamos Vossa Senhoria que a ex-vereadora, Senhora recolheu aos cofres municipais, a quantia de $R \$ 438,44$ (quatrocentos e trinta e oito reais e quarenta e quatro centavos), referente aos seus subsídios recebidos a maior no ano de 2.009, devidamente corrigida, conforme esclarecem os comprovantes anexos. Os pagamentos foram feitos em duas oportunidades, a saber: o primeiro em 27.02.2009 e, o segundo, no dia 31.07.2009, nos valores de $\mathrm{R} \$ 160,00$ (cento e sessenta reais) cada um.

Fonte: dados da pesquisa

Quadro 3 - Síntese do exame dos textos quanto ao parâmetro "vocativo"

\begin{tabular}{|c|c|c|}
\hline Texto & Vocativo & Análise \\
\hline 1 & -- & Inapropriado \\
\hline 2 & Excelentíssimo(a) Senhor(a) Relator(a) & Apropriado \\
\hline 3 & Prezados Senhores & Inapropriado \\
\hline 4 & Prezados (as) Senhor (es) (as) & Inapropriado \\
\hline 5 & Prezado Senhor & Inapropriado \\
\hline 6 & Senhor Conselheiro & Apropriado \\
\hline 7 & Senhor Conselheiro Presidente & Apropriado \\
\hline 8 & À Presidência do Tribunal de Contas do Estado de & Inapropriado \\
\hline 9 & Minas Gerais & Apropriado \\
\hline 10 & Excelentíssimo Senhor & Apropriado \\
\hline 11 & Senhor Relator & Inapropriado \\
\hline
\end{tabular}

Fonte: dados da pesquisa.

\subsection{Pronome de tratamento referente ao destinatário}

Quanto a este parâmetro, o exame se deu no corpo do texto. Considerando que o cargo de conselheiro dos tribunais de contas corresponde ao primeiro escalão da Administração 
2O SEMESTRE DE 2017 - N. 31

Pública, é apropriado somente o pronome de tratamento "V. Exa.”.

Quadro 4 - Síntese do exame dos anexos quanto ao parâmetro "pronome de tratamento"

\begin{tabular}{|c|c|c|}
\hline Anexo & Pronome de tratamento & Análise \\
\hline 1 & V. Exa. & Apropriado \\
\hline 2 & V. SRa.; V. Sra. & Inapropriados \\
\hline 3 & -- & -- \\
\hline 4 & Vossa Senhoria & Inapropriado \\
\hline 5 & -- & -- \\
\hline 6 & Vossa Excelência & Inapropriado \\
\hline 7 & V. Exa. & Apropriado \\
\hline 8 & V. Exa. & Apropriado \\
\hline 9 & V. Exa. & Apropriado \\
\hline 10 & --- & Apropriado \\
\hline 11 & V. Exa. & Apropriado \\
\hline
\end{tabular}

Fonte: dados da pesquisa.

O texto 1 traz "V. Exa." na primeira ocorrência do pronome de tratamento. Mas devemos observar que, no entanto, não condiz com o endereçamento. As demais ocorrências neste Anexo são inapropriadas. O texto 5 é considerado inapropriado por trazer a forma por extenso, adequada somente quando se referir a chefes de poderes.

Figura 6 - Texto 5

Diante do exposto rogamos a Vossa Excelência que seja concedido dilação de prazo para a regularização do processo acima identificado.

$\mathrm{Na}$ aguardo do atendimento da solicifîação, renovamos nossos protestos de elevada estima e consideração.

Atenciosamente,

Fonte: dados da pesquisa

O uso de "V. Sa." procura garantir certa formalidade no texto oficial; entretanto, é inadequado, uma vez que aproxima, hierarquicamente, a pessoa do remetente à do destinatário. Essa prática foi verificada eml (com erro de ortografia) e 3 (por extenso, no entanto é condizente com o vocativo, apesar de não concordar em número). Os textos 2, 4 e 9 não trazem, no corpo dos respectivos textos, pronome de tratamento, o que não configura incorreção de redação. 
7. ISTO POSTO, não sendo a justificativa quanto às avocação da competência aceita por $\vee$. Sra, requer desde já seja deferido novo prazo para que se proceda à eventual correção em primazia ao Poder de Auto Tutela da Administração Pública, bnos termos dos artigos Supra, considerando não haver prejuízo à Beneficiária.

Fonte: dados da pesquisa

\subsection{Fecho-chavão}

Os manuais de redação oficial modernos prescrevem apenas dois modelos para o fecho - "atenciosamente" e "respeitosamente". No entanto, a utilização das fórmulas antigas de cortesia ao final dos ofícios, já abolidas, muitas vezes associada ao uso dos fechos prescritos, tem se mostrado muito comum nas correspondências técnicas enviadas ao TCEMG. São expressões que marcam uma relação de estima, de apreço, entre o remetente e o destinatário, hoje consideradas procedimento de aproximação pessoal inapropriado, já que o objetivo do texto oficial é a comunicação entre órgãos por meio de seus dirigentes. Exemplo de expressão com essa finalidade é "Sem mais para o momento, firmamo-nos com elevada estima e distinta consideração" (texto 3).

Por meio dessas expressões, também se pede a compreensão da autoridade destinatária quanto ao que foi trazido ao seu conhecimento. Ora, se as competências dos membros do TCEMG são definidas por meio da Lei Orgânica e do Regimento Interno do órgão, e se as obrigações dos remetentes encontram-se explicitadas, além de nestes dois diplomas legais (que também os alcançam), nas instruções normativas do TCEMG, nas leis orgânicas de seus municípios e demais estatutos das entidades que dirigem, não há que se solicitar compreensão por parte das autoridades do TCEMG ao ser apresentado pedido já claramente regulamentado, cabendo ao remetente manifestar sua necessidade para que, à luz dos textos legais, seja acolhida ou não. Assim é que o fecho do texto 10 ("Certo de poder contar com a sua compreensão, agradeço e renovo os protestos de estima e consideração.") - com a devida observação de que

7 Os manuais de redação oficial, ao discorrerem sobre o assunto tratado neste item, não o nomeiam fecho-chavão, limitandose a recomendar que se evite o uso de fechos longos e rebuscados. Por meio da ferramenta eletrônica de busca Google, a expressão "fecho-chavão" é detectada em uma apostila de 2008 intitulada "Administração Eclesiástica", autor não identificado no arquivo, que estranhamente traz o texto "Este último parágrafo não está numerado: é o fecho-chavão. Imprime ênfase à redação e é uma das características da redação oficial. Sua pompa dependerá da importância do destinatário."Foi verificada também no arquivo de plano de aulas para 2014 disponibilizado na internet pela Profa. Me. Renata Valente F. Vilela, do Departamento de Gerenciais da Universidade Nove de Julho (São Paulo/ SP) no sentido e com a orientação que trazemos neste artigo. Neste contexto, apresentamos a expressão "fecho-chavão" como objeto teórico de pesquisa com a significação do parágrafo que antecede a assinatura do remetente com a finalidade de saudar o destinatário e apresentar manifestações de estima. 
não é o único com esta redação - é completamente inapropriado, ao invocar que Conselheiro do TCEMG compreenda que o requerente necessita de prorrogação de prazo para prestar esclarecimentos e justificativas no processo em que foram detectadas irregularidades de sua gestão.

Em face dessa expressão, dada a manifestação de interesse por uma condição pessoal e diante da necessidade de postura ética dentro do contexto oficial, devem-se excluir, para o vocábulo "compreensão", os significados de faculdade da inteligência que permita a apreensão do que se diz no texto, uma vez que tal solicitação pelo remetente constituiria um ato grosseiro, e de apelo às características humanas de sensibilidade e compaixão por parte do Conselheiro do TCEMG para a questão que se lhe apresenta, na medida em que, como já dito, os atos normativos disciplinam a matéria, ficando a cargo do remetente proceder ao encaminhamento de sua solicitação para que seja deferida ou não.

Ainda sobre a problemática a respeito do fecho-chavão, que constitui, provavelmente, a ofensa mais habitual ao princípio da impessoalidade presente nas comunicações entre órgãos públicos, o dizer de Ledur é preciso quanto à ineficácia e à impropriedade desse recurso:

A maior prova da inutilidade desse palavreado é que o leitor não o lê, pois sabe que a correspondência, no que interessa, acabou. Sabe ainda que não há sinceridade por parte do signatário na manifestação de estima e consideração, tampouco dos protestos; se houvesse, não usaria tão repetido chavão. O redator precisa saber também que a redação oficial não se presta para a manifestação de sentimentos pessoais, ferindo frontalmente, entre outras, a característica essencial da impessoalidade.

Alegam os praticantes desses modelos a necessidade de iniciar e encerrar as comunicações de forma cortês, elegante. $\mathrm{Na}$ verdade, se o ambiente requer objetividade, concisão, impessoalidade, clareza, precisão e rapidez, nada mais descortês e deselegante do que iniciar e encerrar com os chavões, as inutilidades e as imprecisões presentes nesses modelos. É preciso estar atento ao que interessa hoje ao destinatário, e não ao que podia interessar dezenas de anos atrás. (LEDUR, 2007, p. 15, grifo do autor).

Quadro 5 - síntese do exame dos textos quanto ao parâmetro "fecho-chavão"

\begin{tabular}{|c|c|c|}
\hline Texto & Fecho-chavão apresentado & Análise \\
\hline 1 & $\begin{array}{c}\text { Sendo só para o momento. Elevamos nossos } \\
\text { protestos de distinta estima e consideração. (sic) }\end{array}$ & Inapropriado \\
\hline 2 & $\begin{array}{c}\text { Desde já agradecemos a habitual atenção e } \\
\text { nos colocamos a disposição para quaisquer } \\
\text { esclarecimentos que se fizer necessário. (sic) }\end{array}$ & Inapropriado \\
\hline 3 & $\begin{array}{c}\text { Sem mais para o momento, firmamo-nos com } \\
\text { elevada estima e distinta consideração. }\end{array}$ & Inapropriado \\
\hline
\end{tabular}




\begin{tabular}{|c|c|c|}
\hline 4 & -- & Apropriado \\
\hline 5 & $\begin{array}{l}\text { No aguardo do atendimento da solicitação, } \\
\text { renovamos nossos protestos de elevada estima e } \\
\text { consideração. }\end{array}$ & Inapropriado \\
\hline 6 & $\begin{array}{l}\text { Sem mais para o momento e certo da } \\
\text { compreensão de V. Exa., desde já agradeço e } \\
\text { coloco-me ao inteiro dispor. }\end{array}$ & Inapropriado \\
\hline 7 & $\begin{array}{l}\text { Aproveitamos para renovar protestos de elevada } \\
\text { estima e distinta consideração. }\end{array}$ & Inapropriado \\
\hline 8 & -- & Apropriado \\
\hline 9 & -- & Apropriado \\
\hline 10 & $\begin{array}{c}\text { Certo de poder contar com a sua compreensão, } \\
\text { agradeço e renovo os protestos de estima e } \\
\text { consideração. }\end{array}$ & Inapropriado \\
\hline 11 & -- & Apropriado \\
\hline
\end{tabular}

Fonte: dados da pesquisa.

\subsection{Fecho 8}

Conforme já mencionado na abordagem do parâmetro "fecho-chavão", aceitamse atualmente apenas "atenciosamente" e "respeitosamente", de acordo com a combinação entre o nível de hierarquia do remetente e o do destinatário, independentemente do grau de proximidade porventura existente entre eles. "Respeitosamente" deve ser empregado quando o remetente se reporta a alguém que lhe é hierarquicamente superior, ao passo que "atenciosamente" se dá nos casos em que ambos têm o mesmo grau hierárquico ou em que a correspondência é encaminhada a quem ocupe posição hierárquica inferior.

Considerando que as correspondências técnicas sob exame são encaminhadas por chefes dos poderes da administração direta ou por dirigentes de entidades da administração indireta municipal aos membros do TCEMG, estando, portanto, os destinatários sempre em posição hierárquica superior aos remetentes, a única possibilidade de fecho é "respeitosamente", a qual, muito curiosamente, não ocorreu em nenhum dos documentos desta pesquisa.

8 O Manual de Redação Parlamentar da Assembleia Legislativa do Estado de Minas Gerais (2013) o denomina "fecho de cortesia" (p. 252). 
Quadro 6 - síntese dos textos quanto ao parâmetro "fecho"

\begin{tabular}{|c|c|c|}
\hline Anexo & Fecho apresentado & Análise \\
\hline 1 & Termos em que pede deferimento & $\begin{array}{c}\text { Condizente com o } \\
\text { gênero apresentado } \\
\text { (requerimento) } \\
\text { Inapropriado }\end{array}$ \\
\hline 2 & Atenciosamente & Inapropriado \\
\hline 3 & Cordialmente & $\begin{array}{c}\text { Inapropriado, embora } \\
\text { condizente com o } \\
\text { gênero apresentado } \\
\text { (requerimento) }\end{array}$ \\
\hline 4 & Nestes termos, peço deferimento & \begin{tabular}{c} 
Inapropriado \\
\hline 5
\end{tabular} \\
\hline 6 & Atenciosamente & Inapropriado \\
\hline 7 & -- & Inapropriado \\
\hline 8 & Atenciosamente & Inapropriado \\
\hline 9 & Cordialmente & Inapropriado \\
\hline 10 & Atenciosamente & Inapropriado \\
\hline 11 & Atenciosamente & Apropriado \\
\hline
\end{tabular}

Fonte: dados da pesquisa.

A não utilização do fecho por meio do qual o remetente encerra sua comunicação a uma autoridade superior pode ser entendida como uma tentativa de aproximação do emissor em relação ao receptor, se levarmos em conta que as ocorrências inadequadas ("atenciosamente" nos textos 2, 5, 7, 9 e 10, e "cordialmente" nos textos 3 e 8) se deram sempre após o emprego do fecho-chavão discutido anteriormente, cujas expressões simbolizam relação de estima entre os interlocutores e são tidas como abordagem pessoal inapropriada na comunicação entre órgãos públicos.

Há casos em que o remetente, embora esteja entre as autoridades que podem encaminhar ao TCEMG as correspondências técnicas examinadas nesta pesquisa, devem se manifestar em razão de aspectos que envolvem direitos pessoais, mesmo que atinentes aos processos em que são partes, em vez de fazê-lo em nome do órgão que representa. São os casos em que a correspondência trata de requerimento.

O Manual de Redação Oficial do Governo do Estado de Minas Gerais (2012) não contempla este gênero, enquanto o Manual de Redação Parlamentar da Assembleia Legislativa do Estado de Minas Gerais (2013) o trata sob o ponto de vista das atividades parlamentares. 


\section{（ESPUC}

No âmbito federal, o requerimento é trabalhado em capítulos especiais, a título de exemplo, do Manual de Redação e de Atos Oficiais da Agência Nacional de Águas (2005) e do Manual de Padronização de Atos Oficiais Administrativos do Tribunal Superior Eleitoral (2009). Este último, em palavras semelhantes à do primeiro, o define como "instrumento por meio do qual o requerente dirige-se à autoridade administrativa para solicitar um direito ou a concessão de pedido, sob o amparo de lei ou norma reguladora" (BRASIL, 2009, p. 137).

Os modelos de requerimento destes manuais e de muitas apostilas de cursos de redação oficial encontradas na internet via ferramenta de busca Google são sempre apresentados com redação na $3^{\text {a }}$ pessoa do singular e apresentam como fecho adequado "Termos em que pede deferimento" (e suas variações "Termos em que se pede deferimento" e "Nestes termos, pede deferimento" ou, simplesmente, "Pede Deferimento"), que foi corretamente utilizado no texto 11. Diante de todo o exposto, quanto ao requerimento e tendo em vista o tema desenvolvido neste artigo, a variante "peço deferimento" é considerada inapropriada (texto 4).

Figura 8 - Texto 4

Assim sendo, solicito a liberação no sistema para que $p c$ ar a situação no FISCAP, bem como obter o registro dos referidos ato:

Nestes termos, peço deferimento.

Fonte: dados da pesquisa.

Houve exemplar de correspondências técnicas redigidas segundo o modelo do requerimento, mas que deveriam ter sido encaminhadas como ofício, pois a comunicação se dava entre órgãos. A análise do fecho foi considerada condizente ou não condizente com o gênero apresentado, uma vez que apropriado ou não apropriado não mais cabia (vide texto 1). Houve, ainda, correspondências técnicas redigidas com indefinição quanto ao gênero: foram detectados ofício com o fecho do requerimento (texto 4) e requerimento com fecho de ofício (texto 10). 


\section{CESPUC}

\section{Romero de Assis (aixeta}

Figura 9 - Texto 10

Certo de poder contar com a sua compreensão, agradeço e

renovo os protestos de estima e consideração.

Atenciosamente,

Fonte: dados da pesquisa.

\section{Conclusão}

Diante dos resultados obtidos e de toda a discussão até aqui apresentada acerca das características dos gêneros oficiais, podemos afirmar que as correspondências técnicas (de vários órgãos) dirigidas ao TCEMG têm bem pouca aderência às normas de redação oficial de modo geral e, no tocante ao objeto desta pesquisa, veiculam muitas marcas de pessoalidade. $\mathrm{O}$ revisor, de posse dos saberes teóricos de referência e com possibilidades de gerenciamento das múltiplas vozes que intervêm no texto (do remetente, do destinatário, do próprio revisor e, se houver, do redator), tem, notoriamente, material que requer intervenção intensa com vistas ao refinamento dos parâmetros discursivos.

Pudemos demonstrar o quanto o trabalho do revisor de texto pode ser árduo; são necessárias várias leituras do material e das prescrições para garantir o domínio sobre os aspectos da redação oficial e sobre a matéria tratada em cada ato, em particular.

Ademais, a partir do exame acurado de todas as correspondências técnicas, vê-se que as operações cabíveis não são restritas apenas à adequação aos ditames das normas de redação oficial. Com efeito, as impropriedades são de ordem linguística (abreviações, concordância, regência, orações desgarradas, coesão, etc.) e gráfica (composição visual e material do texto na página). Há vários exemplos de defeitos surpreendentes a demandar o procedimento da reescrita que abarque parâmetros discursivos, textuais e linguísticos e permita o surgimento de uma nova versão de um texto capaz de atender os critérios da correção e da legibilidade.

Considerando a frequência com que muitas inadequações relativas às marcas de pessoalidade se apresentaram nos documentos encaminhados pelos chefes dos poderes da Administração Pública dos municípios mineiros e pelos dirigentes das entidades da administração indireta municipal ao Tribunal de Contas do Estado de Minas Gerais, constatamos que há espaço para um novo estudo que busque compreender as possíveis causas que favoreçam as várias manifestações deste fenômeno específico, para além da ausência do profissional revisor no âmbito daquelas entidades. Um objeto de pesquisa possível é aquele que leva em conta o 


\section{CESPUC \\ 2O SEMESTRE DE $2017-$ N. 31}

percurso histórico das relações entre as entidades municipais e os órgãos estaduais, bem como o que considera as relações mesmas entre os subscritores e os destinatários, ferindo, por via de consequência, os critérios da redação oficial, tendo em vista que cinco dos sete membros do TCEMG são egressos de órgãos políticos de notória expressão em suas respectivas regiões e/ou no âmbito estadual, o que corresponde a $71,4 \%$ dos Conselheiros.

\section{Referências}

BOSSI, Alexandre. http://alexandrebossi.com.br. Acesso em: 18 mar. 2015.

BRASIL. Agência Nacional de Águas. Manual de Redação e de Atos Oficiais. Brasília: ANA, SGE, CEDOC, 2007. 73 p. Disponível em: <http://arquivos.ana.gov.br/resolucoes/2007/4802007-anexol.pdf> Acesso em: 7 mai. 2015.

BRASIL. [Constituição (1988)] Constituição da República Federativa do Brasil de 1988. Brasília, Senado, 2015. Disponível em: < http://www.planalto.gov.br/ccivil_03/constituicao/ constituicaocompilado.htm>. Acesso em: 22 mar. 2015.

BRASIL. Presidência da República. Manual de Redação da Presidência da República. 2. ed. Brasília: Presidência da República, 2002. 130 p. Disponível em: < http://www.planalto.gov.br/ ccivil_03/manual/manual.htm> Acesso em: 23 mar. 2015.

BRASIL. Tribunal Superior Eleitoral. Manual de Padronização de Atos Oficiais Administrativos do Tribunal Superior Eleitoral. 2a ed. rev. e ampl. Brasília: TSE/SGI, 2009. 198p. Disponível em: <http://www.tse.jus.br/hotSites/CatalogoPublicacoes/.../manual_versao_web.pdf> Acesso em: 7 mai. 2015.

CASTRO, Marcílio França. Entre o texto e o contexto: a técnica legislativa além da regra. Cadernos da Escola do Legislativo, Belo Horizonte, v.4, n.7, p.121-147, jan./jun. 1998.

COELHO, Sueli Maria; ANTUNES, Leandra B. Revisão textual: para além da revisão linguística. Revista Scripta, Belo Horizonte, v. 14, n.26, p. 205-224, $1^{\circ}$ sem. 2010. Disponível em: <http://periodicos.pucminas.br/index.php/scripta/article/view/4361>. Acesso em: 13 abr. 2015.

D'ANDREA, C.F.B. \& RIBEIRO, Ana Elisa. Retextualizar e reescrever, editar e revisar: Reflexões sobre a produção de textos e as redes de produção editorial. Veredas On Line - Atemática. Juiz de Fora, n. 1, p. 64-74, 2010. Disponível em: <http://www. ufjf.br/revistaveredas/files/2010/08/ARTIGO-5.pdf>. Acesso em: 8 abr. 2015. DIAS, Daniella L. Aspectos interacionais dos textos institucionais. Revista Scripta, Belo Horizonte, v. 14, n. 26, p. 151-162. $1^{\circ}$ sem. 2010. Disponível em: < http://periodicos.pucminas. br/index.php/scripta/article/viewFile/4357/4502 >. Acesso em: 25 mar. 2015. 


\section{CESPUC}

LEDUR, Paulo Flávio. Manual de Redação Oficial dos Municípios. Porto Alegre: Editora Age Ltda., 2007. 115 pág.

LIMA, Antônio Oliveira. Normas da Correspondência Oficial. In: Manual de Redação Oficial: teoria, modelos e exercícios. $2^{\mathrm{a}}$ ed., Rio de Janeiro: Elsevier Editora Ltda., 2005. p. 7-18.

MINAS GERAIS. Assembleia Legislativa do Estado de Minas Gerais. Manual de Redação Parlamentar. $3^{\mathrm{a}}$ ed. Belo Horizonte: 2013. Disponível em: < http://www.almg.gov.br/ opencms/export/sites/default/consulte/publicacoes_assembleia/cartilhas_manuais/arquivos/ pdfs/manual_parlamentar/manual_de_redacao_parlamentar3.pdf > . Acesso em: 10 mar. 2015.

MINAS GERAIS. [Constituição (1989)] Constituição do Estado de Minas Gerais. 16. ed. - Belo Horizonte: Assembleia Legislativa do Estado de Minas Gerais, 2015. Disponível em: < http://www.almg.gov.br/opencms/export/sites/default/consulte/publicacoes_assembleia/ cartilhas_manuais/arquivos/pdfs/manual_parlamentar/manual_de_redacao_parlamentar3. pdf > . Acesso em: 22 mar. 2015.

MINAS GERAIS. Governo do Estado de Minas Gerais. Manual de redação oficial. Belo Horizonte: 2012. Disponível em: <http://www.mg.gov.br/governomg/portal/c/governomg/ governo/acoes-do-governo/516363-manual-de-redacao-oficial/5794/5040>. Acesso em: 12 mar. 2015.

MINAS GERAIS. Tribunal de Contas do Estado de Minas Gerais. Lei Orgânica do Tribunal de Contas do Estado de Minas Gerais. Disponível em <http://www.tce.mg.gov.br/IMG/ Legislacao/legiscont/Leioorganica/LEI\%20ORG\%C3\%82NICA\%20\%20-\%20LC\%2010208\%20_Atualizada_.pdf $>$. Acesso em: 6 mar. 2015.

MINAS GERAIS. Tribunal de Contas do Estado de Minas Gerais. Regimento Interno do Tribunal de Contas do Estado de Minas Gerais. Disponível em <http://tclegis.tce.mg.gov.br/ Home/DownloadPDF/978636>. Acesso em: 6 mar. 2015.

MORAIS, Ana C. C. A. A Adequação dos Textos Normativos Produzidos pelo Instituto Serzedello Corrêa às Normas de Redação Oficial. 201 1, 58 p. Trabalho de Conclusão de Curso (Especialização) - Faculdade WDIREITO, Brasília. Disponível em < portal2.tcu.gov.br/portal/ pls/portal/docs/2508094.PDF > . Acesso em: 21 fev. 2015.

PERPÉTUA, Elzira Divina; GUIMARÃES, Raquel Beatriz Junqueira. A revisão do texto literário: um trabalho de memória. Revista Scripta, Belo Horizonte, v.14, 2010. Disponível em: <http://periodicos.pucminas.br/index.php/scripta/article/viewFile/4360/4505> . Acesso em: 6 mar. 2015.

RIBEIRO, Ana Elisa. Em busca do texto perfeito: (in)distinções entre as atividades do editor de texto e do revisor de provas na produção de livros. In: CONGRESSO BRASILEIRO DE CIÊNCIAS DA COMUNICAÇÃO DA REGIÃO SUDESTE, 12, 2007, Juiz de Fora. Anais eletrônicos... Juiz de Fora: Intercom, 2007. Disponível em: <http://www.intercom.org.br/ papers/regionais/sudeste2007/resumos/R00111.pdf>. Acesso em: 15 mar. 2015. 


\section{CESPUC}

\section{Romero de Assis (aixeta}

VILELA, Renata V. F. https://renatavalente.wordpress.com/. Acesso em: 22 abr. 2015.

YAMAZAKI, Cristina. Editor de textos: quem é e o que faz? In: CONGRESSO BRASILEIRO DE CIÊNCIAS DA COMUNICAÇÃO, 30, 2007, Santos. Anais eletrônicos... Santos: Intercom, 2007. Disponível em: <http://www.intercom.org.br/papers/nacionais/2007/ resumos/R1 153-1.pdf>. Acesso em: 25 mar. 2015. 